\title{
Research on Supply and Demand of Cold Chain Logistics of Fresh Agricultural Products in Liaoning Province
}

\author{
Xiaopeng Zhao \\ City Institute of Dalian University of Technology, Dalian, China \\ Email: zxp7324@163.com
}

How to cite this paper: Zhao, X. P. (2020). Research on Supply and Demand of Cold Chain Logistics of Fresh Agricultural Products in Liaoning Province. American Journal of Industrial and Business Management, 10, 723-733.

https://doi.org/10.4236/ajibm.2020.104049

Received: March 13, 2020

Accepted: April 11, 2020

Published: April 14, 2020

Copyright $\odot 2020$ by author(s) and Scientific Research Publishing Inc. This work is licensed under the Creative Commons Attribution International License (CC BY 4.0).

http://creativecommons.org/licenses/by/4.0/

\begin{abstract}
In recent years, with the country's attention to the circulation of agricultural products and the rapid development of fresh e-commerce, cold chain logistics has been developed rapidly. Based on the investigation of the circulation of fresh agricultural products including fruits and vegetables, fresh meat, aquatic products, milk and eggs, the paper first studies the cold chain logistics supply and demand of fresh agricultural products in Liaoning province. Then the contradiction between supply and demand of cold chain logistics is analyzed, and finally, a series of suggestions to solve the contradiction are given in combination with the existing cold chain logistics resources and the logistics demand of fresh agricultural products in Liaoning Province.
\end{abstract}

\section{Keywords}

Fresh Produce, Cold Chain Logistics, Logistics Supply and Demand

\section{Introduction}

Since the 11th Five-Year Plan, Liaoning Province has entered the ranks of the country's major agricultural provinces. In addition to rice and other kinds of grain, Liaoning Province is also rich in fruits and vegetables such as cherries, strawberries and tomatoes, which not only meet the daily consumption of residents in the province, but also sell some of them to other provinces and export to other countries such as Japan. Table 1 shows the production of fresh agricultural products in Liaoning Province in recent years. In addition, Liaoning Province is rich in aquatic products, and the output is in the top five in the country. The above fresh agricultural products, as well as the circulation of meat, milk and eggs, need cold chain logistics. It can be seen that the demand for cold chain logistics in Liaoning Province is very large. 
Table 1. Output of fresh agricultural products in Liaoning Province, 2010-2017.

\begin{tabular}{cccccccc}
\hline Output (10,000 tons) Year & fresh vegetables & fresh fruits & aquatic product & eggs & milk & meat \\
\hline 2010 & 2668.2 & 468.97 & 429.1 & 275.70 & 126.70 & 406.70 \\
2011 & 2832.5 & 514.73 & 453.9 & 277.40 & 132.00 & 408.20 \\
2012 & 2977.6 & 554.19 & 480.8 & 279.90 & 130.20 & 418.70 \\
2013 & 3171.4 & 582.83 & 504.9 & 278.20 & 125.70 & 420.30 \\
2014 & 3090.1 & 526.48 & 515.7 & 280.10 & 134.50 & 429.18 \\
2015 & 2932.8 & 543.48 & 523.7 & 277.10 & 142.60 & 429.40 \\
2016 & 2257.5 & 543.88 & 479.9 & 287.90 & 144.2 & 430.90 \\
2017 & 2048.0 & 558.49 & 479.4 & 270.40 & 120.7 & 385.40 \\
\hline
\end{tabular}

Note: the data of the output of fresh agricultural products in Liaoning Province is obtained from the Statistical Yearbook of Liaoning Province and the Statistical Yearbook of China.

According to the survey, the supply of cold chain logistics of fresh agricultural products in Liaoning Province is not optimistic. In addition to Dalian Gang Yidu Cold Chain Co., Ltd. and China Railway Iron Dragon Cold chain Development Co., Ltd. and other state-owned enterprises with strong background, third-party cold chain logistics enterprises are few. By 2017, Liaoning's cold storage capacity was more than 1.53 million tons, and even if all were used for the storage of fresh agricultural products, the refrigerated storage rate was much lower than that of developed countries in Europe and the United States. Because the cost of refrigerated trucks is too high, most of the fresh agricultural products are transported by normal temperature vehicles, through ice bags or quilts for temperature control, the temperature fluctuation in the transportation process is relatively large. Up to now, the cold chain logistics network in Liaoning Province is not perfect, and the supply capacity of cold chain logistics needs to be improved.

Based on the above background, this paper will deeply study the current situation of cold chain logistics supply and demand in Liaoning Province and the contradictions between them by combining qualitative and quantitative methods, and provide practical suggestions to solve these contradictions.

\section{Cold Chain Logistics of Fresh Agricultural Products}

\subsection{Concept and Characteristics of Fresh Agricultural Products}

The national standard of the People's Republic of China defines fresh agricultural products as that: fresh agricultural products, including vegetables, fruits, livestock meat, aquatic products, fresh eggs and so on, are not processed or primary processed through planting, breeding, harvesting and fishing. Thus it can be seen, the scope of fresh agricultural products is: fresh vegetables, fresh fruits, fresh aquatic products, live livestock and fresh meat, eggs and milk.

Compared with other products, fresh agricultural products have the characteristics of short storage period, easy damage and easy deterioration ( $\mathrm{Xu}, 2016)$. 
Because of these characteristics, it has a high demand for temperature and efficiency in the process of logistics.

\subsection{The Connotation and Characteristics of Cold Chain Logistics of Fresh Agricultural Products}

The 12th Five-Year Plan for Cold Chain Logistics Development of Agricultural Products in China clearly points out: The cold chain logistics of agricultural products refers to the special supply chain system which ensures the quality of products, reduces wastage and prevents pollution to the greatest extent through constant low temperature control in product processing, storage, transportation, distribution and retailing, after the fresh agricultural products such as meat, poultry, aquatic products, vegetables, fruits and eggs are harvested from the origin. It can be seen that the cold chain logistics system for fresh agricultural products integrates the technology of temperature control, logistics management, food quality management and other skills into a complex supply chain system. Compared with the ordinary commodity logistics system, the system has the following characteristics: 1) the whole cold chain logistics of fresh agricultural products need temperature control (Ma and Huang, 2017). 2) The cold chain logistics of fresh agricultural products combines the knowledge and skills of logistics management, food quality management, refrigeration technology, freezing technology and so on, and the complexity is relatively high. 3) Fresh agricultural products cold chain logistics needs refrigerated vehicles, cold storage and other specialized equipments, resulting in a higher initial logistics cost investment.

\section{Analysis of Cold Chain Logistics Demand for Fresh Agricultural Products in Liaoning Province}

\subsection{Demand Situation and Demand Characteristics}

According to the survey, the demand for cold chain logistics of fresh agricultural products in Liaoning Province is shown in Table 2 below.

As can be seen from Table 2, the cold chain logistics demand for fresh agricultural products in Liaoning Province presents the following characteristics:

1) In addition to hot fresh meat, other fresh agricultural products need to be pre-cooled after harvest. Pre-cooling is the first step for fresh agricultural products to enter the cold chain system, and it also directly determines the fresh-keeping quality and fresh-keeping time. In order to realize the pre-cooling, grading, packing and standardization for the first time after picking, fresh agricultural products must have perfect cold chain logistics infrastructure, such as cold storage, pre-cooling room and so on, and the requirement of pre-cooling technology is high.

2) The whole process of fresh agricultural products circulation needs temperature control. Although the most suitable circulation temperature of different fresh agricultural products is different, it is necessary to ensure the whole cold chain, so as to ensure the freshness and extend the shelf life. 
Table 2. Cold chain logistics demand for fresh agricultural products in Liaoning province.

\begin{tabular}{|c|c|c|c|c|c|c|c|c|}
\hline \multirow[b]{2}{*}{$\begin{array}{l}\text { Agricultural } \\
\text { products who } \\
\text { need cold } \\
\text { chain logistics }\end{array}$} & \multicolumn{3}{|c|}{ Fresh fruits and vegetables } & \multirow[b]{2}{*}{$\begin{array}{l}\text { Aquatic } \\
\text { product }\end{array}$} & \multirow[b]{2}{*}{ Eggs } & \multirow[b]{2}{*}{ Milk } & \multicolumn{2}{|c|}{ Meat } \\
\hline & $\begin{array}{l}\text { Fruits and } \\
\text { vegetables } \\
\text { Suitable for } \\
\text { low } \\
\text { temperature } \\
\text { storage and } \\
\text { transportation }\end{array}$ & $\begin{array}{l}\text { Fruits and } \\
\text { vegetables } \\
\text { less } \\
\text { sensitive } \\
\text { to cold } \\
\text { damage }\end{array}$ & $\begin{array}{l}\text { Cold } \\
\text { sensitive } \\
\text { fruits and } \\
\text { vegetables }\end{array}$ & & & & $\begin{array}{l}\text { Chilled fresh } \\
\text { meat }\end{array}$ & Hot fresh meat \\
\hline $\begin{array}{l}\text { Temperature } \\
\text { requirements } \\
\left({ }^{\circ} \mathrm{C}\right)\end{array}$ & $-1-5$ & $5-8$ & $8-12$ & 0 & 0 & $2-6$ & $0-5$ & $\begin{array}{l}\text { Normal } \\
\text { temperature }\end{array}$ \\
\hline $\begin{array}{l}\text { Cold chain } \\
\text { logistics } \\
\text { requirements }\end{array}$ & $\begin{array}{l}\text { Post-harvest se } \\
\text { temperature-co } \\
\text { transportation }\end{array}$ & $\begin{array}{l}\text { lection, pre } \\
\text { ontrolled } \\
\text { and wareh }\end{array}$ & $\begin{array}{l}\text { e-cooling, } \\
\text { ousing }\end{array}$ & $\begin{array}{l}\text { Cooling or } \\
\text { micro-freezing, } \\
\text { temperature } \\
\text { controlled } \\
\text { transport and } \\
\text { warehousing }\end{array}$ & $\begin{array}{l}\text { Pre-cooling, } \\
\text { temperature-controlled } \\
\text { transportation and } \\
\text { warehousing }\end{array}$ & $\begin{array}{l}\text { Cooling, sterilization, } \\
\text { filling, temperature } \\
\text { controlled } \\
\text { transportation and } \\
\text { warehousing }\end{array}$ & $\begin{array}{l}\text { Cooling after } \\
\text { slaughter, } \\
\text { temperature } \\
\text { controlled } \\
\text { transportation } \\
\text { and } \\
\text { warehousing }\end{array}$ & $\begin{array}{l}\text { The whole } \\
\text { circulation } \\
\text { process does }\end{array}$ \\
\hline $\begin{array}{l}\text { Requirements } \\
\text { for cold chain } \\
\text { facilities }\end{array}$ & $\begin{array}{l}\text { Pre-cooling roc } \\
\text { storage, temper } \\
\text { transport vehic }\end{array}$ & $\begin{array}{l}\text { om, air-con } \\
\text { rature-cont } \\
\text { cles }\end{array}$ & $\begin{array}{l}\text { aditioned } \\
\text { trolled }\end{array}$ & $\begin{array}{l}\text { Cooling or } \\
\text { micro-freezing } \\
\text { equipment, } \\
\text { cold storage, } \\
\text { refrigerated } \\
\text { transport } \\
\text { vehicles }\end{array}$ & $\begin{array}{l}\text { Pre-cooling room, } \\
\text { temperature-controlled } \mathrm{t} \\
\text { storage \&transport } \\
\text { vehicles }\end{array}$ & $\begin{array}{l}\text { Pre-cooling room, } \\
\text { temperature-controlled } \\
\text { storage \& transport } \\
\text { vehicles }\end{array}$ & $\begin{array}{l}\text { Pre-cooling } \\
\text { room, cold } \\
\text { storage, } \\
\text { refrigerated } \\
\text { transport } \\
\text { vehicles }\end{array}$ & $\begin{array}{l}\text { not carry on the } \\
\text { temperature } \\
\text { control, the } \\
\text { microorganism } \\
\text { cannot be } \\
\text { restrained, easy } \\
\text { to pollute, }\end{array}$ \\
\hline $\begin{array}{l}\text { Quality } \\
\text { requirements } \\
\text { for cold chain } \\
\text { logistics }\end{array}$ & Ensure tempera & ature contr & ol through & out the flow pro & cess from harvest to deliv & ivery to consumers & & $\begin{array}{l}\text { cannot } \\
\text { guarantee the } \\
\text { meat edible } \\
\text { safety }\end{array}$ \\
\hline $\begin{array}{l}\text { Capacity for } \\
\text { cold chain } \\
\text { logistics costs }\end{array}$ & $\begin{array}{l}\text { The affordabilit } \\
\text { logistics costs is } \\
\text { except for a sm } \\
\text { high-value fruit }\end{array}$ & $\begin{array}{l}\text { tty of cold c } \\
\text { s generally } \\
\text { all number } \\
\text { its and vege }\end{array}$ & $\begin{array}{l}\text { chain } \\
\text { low, } \\
\text { rof } \\
\text { tables }\end{array}$ & Generally high & Generally low & Generally low & Medium & \\
\hline $\begin{array}{l}\text { Demand for } \\
\text { cold chain } \\
\text { logistics talent }\end{array}$ & $\begin{array}{l}\text { Cold chain logi } \\
\text { quality manage } \\
\text { skills of the colc }\end{array}$ & $\begin{array}{l}\text { istics grassr } \\
\text { ement, refri } \\
\text { ld chain log }\end{array}$ & $\begin{array}{l}\text { roots opera } \\
\text { igeration te } \\
\text { jistics }\end{array}$ & $\begin{array}{l}\text { tors and middle } \\
\text { echnology, refrig }\end{array}$ & $\begin{array}{l}\text { and senior management } \\
\text { eration technology, infor }\end{array}$ & $\begin{array}{l}\text { thersonnel who master } \\
\text { ormation technology and }\end{array}$ & $\begin{array}{l}\text { logistics manag } \\
\text { d other areas of }\end{array}$ & $\begin{array}{l}\text { gement, food } \\
\text { f knowledge and }\end{array}$ \\
\hline
\end{tabular}

3) Fresh agricultural products have higher requirements for logistics equipments. Fresh agricultural products from harvest to the hands of consumers, need precooling room, temperature control warehouse and transport vehicles and other temperature control equipments, these facilities equipment is usually more expensive than ordinary logistics equipment.

4) The circulation of fresh agricultural products needs the specialized personnel of cold chain logistics to operate and manage. These professionals not only need to have logistics management related knowledge and experience, but also need refrigeration, food quality control and other related knowledge.

\subsection{Demand Projections}

Fresh agricultural products in Liaoning province mainly meet the living needs of local rural and urban residents, because the part of the consumption of rural 
residents basically belongs to self-production and marketing, almost no flow of goods, so the logistics of fresh agricultural products mainly depends on the consumption of urban residents. Based on the annual purchases of meat, fruits and vegetables, aquatic products, eggs and milk by urban residents (as shown in Table 3), this paper uses the linear quadratic index smoothing method to predict the cold chain logistics of fresh agricultural products (Feng, 2016).

After many trial calculations, when $\mathrm{a}=0.9$, the mean variance is the smallest, so $\mathrm{a}=0.9$ is used to predict the linear quadratic exponential smoothing method of cold chain material flow rate of fresh agricultural products in Liaoning province from 2019 to 2023. The results are as Table 4.

It can be seen that the cold chain material flow of fresh agricultural products in Liaoning Province in the next five years is increasing year by year.

Table 3. The number of urban residents and per capita purchases of fresh agricultural products in Liaoning Province.

\begin{tabular}{|c|c|c|c|}
\hline Year & $\begin{array}{l}\text { Number of urban residents in } \\
\text { Liaoning Province }(10,000)\end{array}$ & $\begin{array}{l}\text { Per capita purchase of fresh } \\
\text { agricultural products }(\mathrm{kg})\end{array}$ & $\begin{array}{l}\text { Total amount of fresh agricultural products } \\
\text { purchased by urban residents }(10,000 \text { tons })\end{array}$ \\
\hline 2003 & 2357.60 & 91.09 & 214.75 \\
\hline 2004 & 2361.50 & 326.34 & 770.65 \\
\hline 2005 & 2477.73 & 319.73 & 792.2 \\
\hline 2006 & 2519.46 & 330.35 & 832.3 \\
\hline 2007 & 2544.42 & 267.91 & 681.68 \\
\hline 2008 & 2591.158 & 287.57 & 745.14 \\
\hline 2009 & 2619.794 & 281.23 & 736.76 \\
\hline 2010 & 2716.875 & 257.11 & 698.54 \\
\hline 2011 & 2807.312 & 270.58 & 759.6 \\
\hline 2012 & 2881.379 & 270.37 & 779.04 \\
\hline 2013 & 2917.155 & 259.11 & 755.86 \\
\hline 2014 & 2944.166 & 259.94 & 765.31 \\
\hline 2015 & 2951.277 & 260.75 & 769.55 \\
\hline 2016 & 2949.459 & 265.59 & 783.35 \\
\hline 2017 & 2948.638 & 264.1 & 778.72 \\
\hline 2018 & 2968.479 & 276.5 & 820.78 \\
\hline
\end{tabular}

Note: the data of the number of urban residents in Liaoning Province and the quantity of fresh agricultural products purchased by urban residents per capita are obtained from the Statistical Yearbook of Liaoning Province and the Statistical Yearbook of China.

Table 4. Forecast results of total fresh agricultural products purchased by urban residents in Liaoning province from 2019 to 2023.

\begin{tabular}{ccccccc}
\hline year & 2019 & 2020 & 2021 & 2022 & 2023 \\
\hline Forecast results (10,000 tons) & 854.02 & 887.69 & 921.36 & 955.03 & 988.7 \\
\hline
\end{tabular}




\section{Analysis of Cold Chain Supply of Fresh Agricultural Products in Liaoning Province}

\subsection{Analysis of Logistics Service Mode}

At present, there are three main service modes of cold chain logistics of fresh agricultural products in Liaoning Province:

1) Self-owned Cold Chain Logistics Model. This model is mainly to meet the needs of their own fresh agricultural products for cold chain logistics, self-built cold chain logistics system, more professional, after the development to a certain scale also oriented to social services. At present, the self-owned cold chain logistics model in Liaoning Province is mainly used in the circulation of aquatic products, chilled fresh meat and fresh milk, such as the Bangchuidao Island Group in Dalian, the Zhangzi Island Group, the Liaoyu Group and the Huishan Dairy Industry in Shenyang. This mode accounts for a large proportion of cold chain logistics services in Liaoning Province, and the cold chain logistics network is relatively perfect, and the degree of specialization is relatively high, and logistics costs are also high.

2) Third-party cold chain logistics model. This model mainly provides public cold chain logistics services. Liaoning Province fresh e-commerce mainly adopts the third party cold chain logistics mode, which is used to transport high value fruits and aquatic products, such as cherries and sea cucumbers. At present, the third-party cold chain logistics model is mostly realized through express delivery companies, such as Shunfeng Express delivery and postal EMS (Liu, 2017), but the whole cold chain system is less specialized, mainly through the foam incubator or ice bag to achieve temperature control, which is easy to cause temperature fluctuations and difficult to ensure the quality of fresh agricultural products.

3) The combination of Self-owned and third-party cold chain logistics model. This mode is mainly when self-owned cold chain logistics can't fully meet the needs of enterprises, will use third-party logistics as a supplement. At present, this kind of mixed cold chain logistics mode in Liaoning Province is mainly used in the export logistics of fresh agricultural products such as aquatic products, fruits and vegetables, as well as the sales areas that cannot be covered by the self-owned cold chain logistics system of enterprises.

\subsection{Logistics Suppliers and Their Supply Capacity}

Through investigation, cold chain logistics suppliers in Liaoning Province are mainly concentrated in Dalian and Shenyang cities. There is few integrated third-party cold chain logistics suppliers who can provide integrated services, most of them are enterprises that can provide single function cold chain logistics service such as storage or transportation. According to the service content of cold chain logistics service, the main cold chain logistics suppliers in Liaoning Province are divided into three categories, and the statistics of their own cold chain logistics facilities and cold chain logistics supply capacity are shown in Table 5 below. 
Table 5. Statistical table of major cold chain logistics suppliers in Liaoning province.

\begin{tabular}{|c|c|c|c|c|}
\hline \multirow{2}{*}{$\begin{array}{l}\text { Cold chain logistics } \\
\text { supplier category }\end{array}$} & \multirow[b]{2}{*}{ Enterprise name } & \multicolumn{2}{|c|}{ Cold chain logistics facilities } & \multirow[b]{2}{*}{ Service capability } \\
\hline & & $\begin{array}{l}\text { Cold storage }(10,000 \\
\text { tons })\end{array}$ & Refrigerated vehicles & \\
\hline \multirow{4}{*}{$\begin{array}{l}\text { Cold chain logistics } \\
\text { suppliers based on } \\
\text { warehousing services }\end{array}$} & Shenyang Non-staple Food Group & 12 & No relevant data & \multirow{4}{*}{ Cold storage services } \\
\hline & Zhang Shi Logistics Park & 7.5 & No relevant data & \\
\hline & $\begin{array}{l}\text { Shenyang Chengda Refrigeration } \\
\text { Co., Ltd. }\end{array}$ & 5.5 & No relevant data & \\
\hline & $\begin{array}{l}\text { Dalian Mingfeng Taida Logistics } \\
\text { Co., Ltd. }\end{array}$ & 5 & No relevant data & \\
\hline $\begin{array}{l}\text { Cold chain logistics } \\
\text { suppliers based on } \\
\text { distribution }\end{array}$ & $\begin{array}{c}\text { Dalian city logistics co-distribution } \\
\text { center }\end{array}$ & $21,000 \mathrm{~m}^{2}$ of cold storage & 6 & $\begin{array}{l}\text { Refrigerated distribution in } \\
\text { Dalian }\end{array}$ \\
\hline \multirow{3}{*}{$\begin{array}{c}\text { Integrated cold chain } \\
\text { logistics service suppliers }\end{array}$} & Yurun Group & 20 & 100 & \multirow{2}{*}{$\begin{array}{l}\text { Mainly meet the needs of their } \\
\text { own enterprises for cold chain } \\
\text { logistics }\end{array}$} \\
\hline & Zhangzi Island Group & 10 & No relevant data & \\
\hline & $\begin{array}{c}\text { Dalian Gang Yidu Cold Chain Co., } \\
\text { Ltd. }\end{array}$ & 74 & No relevant data & $\begin{array}{l}\text { Mainly provide the high value } \\
\text { fresh agricultural product } \\
\text { integrated cold chain logistics } \\
\text { services }\end{array}$ \\
\hline
\end{tabular}

As shown in Table 5, Cold chain logistics suppliers based on warehousing services mainly have cold storage resources and mainly provide cold storage services. Cold chain logistics suppliers based on distribution have refrigerated vehicles and mainly provide refrigerated transport services. And integrated cold chain logistics service suppliers have a larger capacity of cold storage, more importantly, they can provide integrated cold chain logistics services.

\subsection{Cold Chain Logistics Coverage and Supply of Fresh Agricultural Products}

According to the investigation, the supply status of cold chain logistics of fresh agricultural products in Liaoning Province is shown in Table 6.

From Table 6, it can be seen that at present, the cold chain logistics coverage rate of fresh agricultural products in Liaoning Province is relatively low, and the supply status of cold chain logistics services is not optimistic.

\section{Analysis on the Contradiction of Supply and Supply of Cold Chain Logistics for Fresh Agricultural Products in Liaoning Province}

According to the above research results, there is a contradiction between supply and demand in the cold chain logistics of fresh agricultural products in Liaoning Province, mainly reflected in the following aspects:

1) Fresh agricultural products need integrated cold chain logistics service, but at present most logistics enterprises can only provide a link of cold chain logistics services. In order to ensure the high quality and low loss of fresh agricultural 
Table 6. Supply status of cold chain logistics of fresh agricultural products in Liaoning Province.

\begin{tabular}{|c|c|c|}
\hline \multicolumn{2}{|c|}{ Fresh Agricultural Products } & Supply status of cold chain logistics \\
\hline \multicolumn{2}{|c|}{ Fresh fruits and vegetables } & $\begin{array}{l}\text { Usually, fruits and vegetables are transported by normal-temperature vehicles, and a small number of } \\
\text { high-value fruits and vegetables are transported by temperature-controlled warehouses and vehicles }\end{array}$ \\
\hline \multicolumn{2}{|l|}{ Eggs } & The entire supply chain is not temperature controlled \\
\hline \multicolumn{2}{|c|}{ Aquatic product } & $\begin{array}{l}\text { Most aquatic products circulate through the producer's own cold chain logistics system, and the system is } \\
\text { relatively perfect }\end{array}$ \\
\hline \multirow{2}{*}{ Meat } & Chilled fresh meat & $\begin{array}{l}\text { Most chilled fresh meats circulate through the producer's own cold chain logistics system, and the system is } \\
\text { relatively perfect, but only accounts for less than } 30 \% \text { of the consumer market }\end{array}$ \\
\hline & Hot fresh meat & $\begin{array}{l}\text { Hot fresh meat accounts for } 60 \% \text { of the consumer market, and the entire supply chain is carried out at room } \\
\text { temperature }\end{array}$ \\
\hline \multicolumn{2}{|l|}{ Milk } & $\begin{array}{l}\text { At present, low-temperature milk currently accounts for only } 20 \% \text { of the dairy market, and small dairy } \\
\text { enterprises and terminal distribution part often cannot guarantee low temperature }\end{array}$ \\
\hline
\end{tabular}

Note: Data on meat in the Table 6 are from the "China Cold Fresh Meat Market Analysis and Research Report 2014-2017" released by Shangpu Consulting. Data on milk comes from the White Paper on Trends in Low Temperature Milk released by the Tmall Innovation Research Center.

products, it is necessary to carry out temperature control in the whole process of circulation and implement the integrated whole cold chain. But at present, most cold chain logistics enterprises in Liaoning Province can only provide logistics services in a certain link, such as refrigerated transportation or storage, and the phenomenon of broken chain is serious.

2) The value of most fresh agricultural products such as fruits, vegetables, eggs and milk consumed by ordinary people is relatively low, which cannot bear the high cost of cold chain logistics (Chen, Cai, and Dai, 2013). According to the above forecast results, the demand space for cold chain logistics of fresh agricultural products, especially low value fresh agricultural products, is huge, but at present, the cost of cold chain logistics in Liaoning Province is high, and the fresh agricultural products with low added value can only be circulated by ordinary logistics, which will inevitably lead to high loss and low quality.

3) The Contradiction between the Demand and Supply of Fresh Agricultural Products hardware and software facilities of high level modern cold chain logistics. Although Liaoning Province currently has more than 1.5 million tons of cold storage capacity, nearly half of the cold storage equipment is old, which cannot meet the precise temperature demand and real-time monitoring of different kinds of fresh agricultural products. Most companies do not yet have refrigerated trucks, mostly insulated by ice cubes or quilts, and lack modern temperature-controlled equipment during transportation. All of these make the temperature control in the circulation of fresh agricultural products cannot be guaranteed.

4) The contradiction between the demand and supply of fresh agricultural products for compound cold chain logistics talents. The complex logistics talents needed for the cold chain logistics operation of fresh agricultural products should not only have the relevant knowledge of logistics management, but also master the knowledge and skills of refrigeration technology, food quality management and other fields. However, although nearly 30 colleges and universities 
in Liaoning Province now have logistics-related majors, there are no schools specialized in training cold chain logistics talents, which makes the shortage of talents in the cold chain logistics of fresh agricultural products.

\section{Suggestions on the Development of Cold Chain Logistics of Fresh Agricultural Products in Liaoning Province}

In view of the above contradiction between supply and demand in the cold chain logistics of fresh agricultural products in Liaoning Province, this paper gives the following suggestions:

1) The upstream and downstream related enterprises in the cold chain industry of fresh agricultural products form a complete system and share the cold chain logistics resources (Ding, 2010). Aiming at the aquatic products and fresh meat enterprises with relatively perfect self-owned cold chain logistics system, such as Zhangzi Island Group, Bangchui Island Group and so on, we can construct the value network with these leading enterprises as the core enterprises, and realize the integrated cold chain logistics operation of this kind of fresh agricultural products from origin to place of sale. For fresh agricultural products, such as fruits, vegetables, milk and eggs, which have not yet established a cold chain logistics system, a value network can be constructed by several third-party cold chain logistics enterprises in the form of enterprise alliance with enterprises associated with fresh agricultural products, so as to realize the integrated cold chain logistics operation of these fresh agricultural products from origin to place of sale.

2) Reduce the cost of cold chain logistics of fresh agricultural products (Wang and Zhang, 2015), so that more fresh agricultural products, especially low value fresh products such as fruits and vegetables can afford cold chain logistics. Speed up the development of third-party cold chain logistics enterprises and expand the coverage of cold chain logistics network in Liaoning Province, it is possible to promote intensive joint distribution and reduce the cost of cold chain logistics, so as to realize the circulation of many fresh agricultural products with low added value in the chain of supply with temperature control. At the same time, the cold storage, cold chain logistics center, refrigerated car and other resources of each cold chain logistics enterprise are encouraged to be reasonably allocated and shared, and the cost of cold chain logistics is reduced as much as possible.

3) Strengthen the research and promotion of new technology of hardware and software facilities in cold chain logistics, and improve the allocation rate of modern facilities and equipment (Liu, 2014). From pre-cooling technology after fresh agricultural products harvest to preservation, temperature control and temperature detection during storage and transportation, and the associated hardware and software facilities need to be continuously studied and popularized in the field of fresh agricultural products circulation in Liaoning Province, so as to improve the allocation rate of modern cold chain facilities and technical equipment and ensure the high quality and efficient circulation of fresh agricul- 
tural products.

4) Colleges and universities in Liaoning Province need to train fresh agricultural products cold chain logistics specialized compound. Relevant colleges and universities in Liaoning Province, especially the applied technology-based colleges and universities that have set up logistics-related majors, should train cold chain logistics complex talents to meet the demand of fresh agricultural products circulation for logistics talents.

\section{Conclusion}

Based on the above research, this paper draws the following conclusions: 1) The potential of cold chain logistics for fresh agricultural products in Liaoning Province is enormous. At present, fresh agricultural products in Liaoning Province have not realized the circulation of cold chain logistics except aquatic products and cold fresh meat. 2) At present, cold chain logistics in Liaoning Province can not meet the demand for fresh agricultural products in terms of hardware and software. 3) Supply and demand for cold chain logistics of fresh agricultural products in Liaoning Province are contradictory in quality and quantity. 4) Liaoning Province can solve the contradiction between supply and demand of cold chain logistics of fresh agricultural products from the aspects of rational allocation of cold chain logistics resources, reduction of cold chain logistics cost and training of cold chain logistics talents.

Although this paper has made some research results, there are some shortcomings: 1) The article does not make the quantitative forecast to the cold chain logistics supply in Liaoning province in the next few years; 2) This paper does not discuss the construction of cold chain logistics system of fresh agricultural products based on value network in detail. These questions will be studied further in the future.

\section{Conflicts of Interest}

The author declares no conflicts of interest regarding the publication of this paper.

\section{References}

Chen, Y. T., Cai, X. E., \& Dai, J. Y. (2013). Evolution of Circulation Pattern of Fresh Agricultural Products. Chinese Journal of Circulation Economy, 3, 19-23.

Ding, J. H. (2010). Value Orientation of Agricultural Product Logistics and Cold Chain Logistics. Chinese Journal of Circulation Economy, 1, 26-28.

Feng, Y. Y. (2016). Prediction of Cold Chain Logistics Demand of Agricultural Products in Beijing. Beijing: North China Electric Power University, 36-42.

Liu, G. (2014). Dynamic Mechanism and Innovation of Circulation Mode of Fresh Agricultural Products. Journal of Business Economics and Research, 1, 33-37.

Liu, G. (2017). Research on Innovation of Logistics Service in Electronic Commerce of Fresh Agricultural Products. Journal of Business Economics and Research, 3, 12-19.

Ma, X. Y., \& Huang, W. (2017). Research on Logistics Development of Guangxi Charac- 
teristic Agricultural Products under the Background of "Internet+". Journal of Price, 1, 82-85.

Wang, Q., \& Zhang, G. B. (2015). Research on Logistics Distribution of Fresh E-Commerce. Journal of Tongling University, 5, 57-64.

$\mathrm{Xu}$, J. (2016). Study on Effective Supply Guarantee of Fresh Agricultural Products in China. Nanjing: Jiangsu University, 29-36. 